\title{
RESEARCH ARTICLE \\ INTERACTIVE EFFECT OF NITROGEN AND PHOSPHORUS ON GROWTH AND YIELD OF HYBRID CAPSICUM (Capsicum annuum L.) IN ROOF TOP GARDEN
}

\author{
Md. Khalid Mahmud ${ }^{1}$, Forhad Hossain ${ }^{2}$, Sk. Monirul Islam ${ }^{1}$, Asraf Ali ${ }^{1}$, Md. Taslim Hossain ${ }^{3}$ \\ ${ }^{1}$ Sher-e-Bangla Agricultural University, Bangladesh \\ ${ }^{2}$ Professor, Sher-e-Bangla Agricultural University \\ ${ }^{3}$ Bangladesh Agricultural University, Bangladesh \\ *Corresponding Author Email: khalid_mahmud_atif@yahoo.com; ashraf.ku11@gmail.com; moonmonirul@gmail.com; \\ taslimmisha.420@gmail.com
}

This is an open access article distributed under the Creative Commons Attribution License, which permits unrestricted use, distribution, and reproduction in any medium, provided the original work is properly cited.

\section{ARTICLE DETAILS}

\section{Article History:}

Received 1 July 2019

Accepted 18 August 2019

Available online 17 September 2019

\section{ABSTRACT}

The experiment was conducted at the roof of third floor of Biotechnology department of Sher-e-Bangla Agricultural University, Dhaka during October, 2017 to March, 2018. The two factorial experiments were laid out in Completely Randomized Design (CRD) with three replications. Here, three levels of nitrogen dose $\mathrm{N}_{0}: 0 \mathrm{~kg} \mathrm{~N} \mathrm{ha-}{ }^{-1}, \mathrm{~N}_{1}: 100 \mathrm{~kg} \mathrm{~N}$ ha- ${ }^{-1}, \mathrm{~N}_{2}: 130 \mathrm{~kg} \mathrm{~N} a^{-1}$ and three levels of phosphorous dose $\mathrm{P}_{0}$ : $0 \mathrm{~kg} \mathrm{P}_{2} \mathrm{O}_{5}$ ha- $^{-1}, \mathrm{P}_{1}: 50 \mathrm{~kg} \mathrm{P}_{2} \mathrm{O}_{5}$ ha- ${ }^{-1}, \mathrm{P}_{2}: 80 \mathrm{~kg} \mathrm{P}_{2} \mathrm{O}_{5}$ ha${ }^{1}$ were used in this experiment. Growth and yield contributing parameters significantly influenced by different doses of nitrogen and phosphorus fertilizers. The dose of $\mathrm{N}_{2}$ treatment gave the highest plant height $(87.45 \mathrm{~cm})$ and most of the growth parameters increased with increasing nitrogen levels up to $\mathrm{N}_{2}$ treatment. The dose of $\mathrm{P}_{2}$ treatment gave the highest plant height $(79.45 \mathrm{~cm})$ and most of the growth parameters increased with increasing phosphorus levels up to $\mathrm{P}_{2}$ treatment. The treatment combination $\mathrm{N}_{2} \mathrm{P}_{2}$ gave the highest fruit diameter $(4.26 \mathrm{~cm})$, fruit length $(11.91 \mathrm{~cm})$, yield of fruits plant- ${ }^{-1}(200 \mathrm{~g})$, average fruit yield plot-1 $(0.81 \mathrm{~kg})$, individual fruit weight $(0.84 \mathrm{~g})$ and average fruit yield ( 6.79 ton/ha). Based on the findings, it can be suggested that the combined use of $130 \mathrm{~kg} \mathrm{~N} \mathrm{ha}^{-1}$ with $80 \mathrm{~kg} \mathrm{P}_{2} \mathrm{O}_{5} \mathrm{ha}^{-1}$ increased plant growth and fruit yield of chili in rooftop garden. It is apparent that growth and yield of Capsicum annuum may be increased by using nitrogen and phosphorus fertilizer except loses through leaching or other factors.

\section{KEYWORDS}

Chili, Roof top garden, NPK, Organic Fertilizer, Nitrogen, Phosphorus.

\section{INTRODUCTION}

The present world is called the world of rapid urbanization. United Nations investigation founded that more than 54 percent of the population of the planet is living in urban areas and they expected to increase the population to 70 percent by 2050 . In that circumstance, rapid urbanization is placed on high demand for urban food supply and security systems. In that situation, urban agriculture plays a significant role to give a possible solution to reduce the impact of this problem [1].

Bangladesh is a densely populated country in the world where more than 175.50 million people are living and urbanization occurs so rapidly in everywhere in Bangladesh. Dhaka, the capital of Bangladesh is one of the fasted growing megacities and the cultivable land in this area has been covered with high rise buildings. In that case, the agricultural land in this locality decreased at an alarming rate [2]. So, rooftop farming can be a workable solution to minimize the food problems as well as make the urban area much more self-sufficient to produce fresh vegetables more reachable to urban area [3]. A recent survey showed that most of the roofs of Dhaka city are suitable for gardening, which doesn't require major improvement but also needs some modifications [2].

In Bangladesh, Capsicum (Capsicum annuum L) is one of the most important vegetable crops in Bangladesh which needs in every cooking process. Due to the practice of Capsicum production on the rooftop garden, Capsicum production will be increased which meets the demand of urban people and also reduce the costs of transport as well as encourage the verities of vegetable production in the urban area. Nitrogen and phosphorus are very important nutrient elements for the growth and development of Capsicum annuum. The profit obtained from the use of organic fertilizers has been so often revealed by the experiment that there is no question about the necessity of using the right fertilizers and the economic returns resulting from them. The optimum doses of fertilizer enhance the growth and yield of crops. It also ensures the availability of other essential nutrient elements for the plant. Fertilizer rates increased capsaicin content and color of green and powered pepper. In general, a large amount of nitrogen fertilizers is required for the growth of the leaf and stem of Capsicum [4]. It also plays a vital role as a constituent of protein, nucleic acid, and chlorophyll. Nitrogen progressively increases the marketable yield, but an adequate supply of nitrogen is essential for vegetative growth, and desirable yield [5]. Phosphorus (P) is the second most frequently limiting macronutrients which are required for optimum growth and reproduction. It is involved in several key plant functions, including energy transfer, photosynthesis, the transformation of sugars and starches, nutrient movement within the plant and transfer of genetic characteristics from one generation to the next [6]. Due to the lack of soil in an urban area, green roof was constructed with less than $20 \%$ organic matter combined with coarse, heat-expanded materials, such as slate or shale. This provides for high permeability and low cation exchange capacity in the soil [7]. For this reason, substrate organic matter breaks down over time. This breakdown of organic matter can result in nutrient leaching. The nutrient loss is higher when the roof ages are gradually increase [8]. In order to maintain rooftop productivity, these lost nutrients must replace. Among all this situation, the application of nitrogen $(\mathrm{N})$ and phosphorus (P) fertilizer in chili production should be judicious. Rooftop farmers should also be especially careful of applying various doses of nitrogen and phosphorus fertilizers will be used and the optimum dose that is beneficial for Capsicum production in rooftop will be identified [9]. Considering the above mentioned facts this experiment will satisfy the following objectives: 1) To find out the optimum dose of nitrogen and phosphorus for growth and maximum yield of Capsicum annuum (hybrid) in rooftop garden; 2) To study the combined effect of nitrogen and phosphorus for obtaining a desirable yield of Capsicum annuum in rooftop. 3) To compare the production of Capsicum in rooftop garden to field condition. 


\section{MATERIALS AND METHODS}

\subsection{Experimental site and land preparation}

The experiment was conducted at the roof of the third floor of Biotechnology department of Sher-e-Bangla Agricultural University, Shere-Bangla Nagar, Dhaka, Bangladesh. The duration of the experiment was October, 2017 to March, 2018. The average maximum temperature during the period of experiment was $29.35^{\circ} \mathrm{C}$ and the average minimum temperature was $15.10^{\circ} \mathrm{C}$. The soil of the experimental site was collected from outside of Dhaka city which was sandy clay. The 30 days old hybrid seedling of winter Capsicum were collected from BARI, Joydebpur, Gazipur. The experiment was laid out in Complete Block Design (CRD) having single factors with three replications. An area of $9 \mathrm{~m} \times 4 \mathrm{~m}$ was divided into three equal blocks. Each block was consists of 9 plots where 2 treatments were allotted two block. There were 27 unit plots in the experiment. The size of each plot was $1 \mathrm{~m} \mathrm{x} 1 \mathrm{~m}$, which accommodated 4 plants at a spacing $0.3 \mathrm{~m} \times 0.3 \mathrm{~m}$. The distance between two blocks and two plots were kept $0.5 \mathrm{~m}$ and $0.25 \mathrm{~m}$ respectively. The doses and application method of fertilizers were given below:

Table 1: Manures and fertilizers application method on Capsicum field

\begin{tabular}{|l|l|l|l|l|l|}
\hline \multirow{2}{*}{$\begin{array}{l}\text { Name of } \\
\text { manure } \\
\text { and } \\
\text { fertilizers }\end{array}$} & \multirow{2}{*}{ Doses/ha } & \multicolumn{4}{|l|}{ Application (\%) } \\
\cline { 3 - 6 } & & Basal & 25 DAT & 50 DAT & 75 DAT \\
\hline Cowdung & $10 \mathrm{ton}$ & 100 & - & - & - \\
\hline Urea $\left(\mathrm{N}_{1}\right)$ & $110 \mathrm{~kg}$ & 50 & 16.67 & 16.67 & 16.67 \\
\hline Urea $\left(\mathrm{N}_{2}\right)$ & $130 \mathrm{~kg}$ & 65 & 16.67 & 16.67 & 16.67 \\
\hline TSP $\left(\mathrm{P}_{1}\right)$ & $50 \mathrm{~kg}$ & 100 & - & - & - \\
\hline TSP $\left(\mathrm{P}_{2}\right)$ & $80 \mathrm{~kg}$ & 100 & - & - & - \\
\hline
\end{tabular}

\subsection{Collection of Data}

Four plants were selected randomly from each plot for data collection in such a way that the border effect could be avoided for the highest precision. Data on the following parameters were recorded from the sample plants during the course of experiment. The data on pant height, number of leaves per plant, leaf length of plant, leaf breadth of plant, number of branches per plant, length of fruit, diameter of fruit, length of pedicel, individual fruit weight, yield of fruits per plant, yield of fruits per plot and yield of fruits per hectare were recorded.

\section{Fruit yield per plot $(\mathrm{kg}) \times 10000\left(\mathrm{~m}^{2}\right)$}

Fruit yield (ton) per hectare $=$

Area of plot in square meter $\left(\mathrm{m}^{2}\right) \times 1000(\mathrm{~kg})$

\subsection{Statistical analysis}

The data obtained from different yield components and yields were statistically analyzed for analysis of variance using the MSTAT-C statistical package program to find out the significance of the difference among the treatments and their combinations. The analysis was performed by Fvariance test, and the significance of the difference between pairs of treatment means was evaluated by the DMRT test at $5 \%$ and $1 \%$ levels of probability.

\section{RESULTS AND DISCUSSION}

\subsection{Effect of nitrogen and phosphorus on morphological parameters of Capsicum}

The plant height of Capsicum was statistically significant with various levels $(30,45,60$ and 75 DAT) of nitrogen (Table 2). The result revealed that at 30 DAT the tallest plant was recorded from $\mathrm{N}_{2}(44.80 \mathrm{~cm})$ which was statistically similar with $\mathrm{N}_{1}(37.33 \mathrm{~cm})$ whereas the shortest plant height was found from $N_{0}$ (23.09). At 45 DAT the highest plant height $(59.91 \mathrm{~cm})$ was observed from the $\mathrm{N}_{2}$ treatment which was statistically similar to $\mathrm{N}_{1}(50.11 \mathrm{~cm})$ whereas, the lowest $(37.33 \mathrm{~cm})$ was observed in $\mathrm{N}_{0}$ treatment. At 65 DAT the highest plant height $(74.44 \mathrm{~cm})$ was observed from the $\mathrm{N}_{2}$ treatment which was statistically similar to $\mathrm{N}_{1}(67.14 \mathrm{~cm})$ whereas, the lowest $(50.95 \mathrm{~cm})$ was observed from $\mathrm{N}_{0}$ treatment. At 75 DAT the highest plant height $(87.45 \mathrm{~cm})$ was observed from the $\mathrm{N}_{2}$ treatment which was statistically similar with $\mathrm{N}_{1}(82.31 \mathrm{~cm})$ whereas, the lowest $(55.78 \mathrm{~cm})$ was observed from $\mathrm{N}_{0}$ treatment. It was revealed that increased plant height up to a certain level then decreases due to increasing the nitrogen fertilizer. The result was similar to that of [10-11]. They observed an improvement in plant height with increasing nitrogen applications. The plant height of Capsicum was statistically significant with various levels $(30,45,60$ and 75 DAT) of phosphorus (Table 2). The result revealed that at 30 DAT the tallest plant was recorded from $\mathrm{P}_{2}$ $(37.24 \mathrm{~cm})$ which was statistically similar with $P_{1}(35.59 \mathrm{~cm})$ whereas the shortest plant height was found from $\mathrm{P}_{0}(32.39 \mathrm{~cm})$. At 45 DAT the highest plant height $(52.66 \mathrm{~cm})$ was observed from the $\mathrm{P}_{2}$ treatment which was statistically similar to $\mathrm{P}_{1}(49.65 \mathrm{~cm})$ whereas, the lowest $(45.69 \mathrm{~cm})$ was observed in $\mathrm{P}_{0}$ treatment. At 65 DAT the highest plant height $(67 \mathrm{~cm})$ was observed from the $\mathrm{P}_{1}$ treatment which was statistically similar to $\mathrm{P}_{2}$ (64.26 $\mathrm{cm})$ whereas, the lowest $(61.26 \mathrm{~cm})$ was observed from $\mathrm{P}_{0}$ treatment. At 75 DAT the highest plant height $(79.45 \mathrm{~cm})$ was observed from the $P_{2}$ treatment which was statistically similar with $P_{1}(75.02 \mathrm{~cm})$ whereas the lowest $(71.08 \mathrm{~cm})$ was observed from $\mathrm{P}_{0}$ treatment. It was revealed that increased plant height up to a certain level then decreases due to increasing the nitrogen fertilizer. It revealed that with the increase of application of phosphorus, plant height showed an increasing trend, but after a certain level plant height increases very slowly. The combined effect of different levels of nitrogen and phosphorus showed a significant variation on plant height of Capsicum at 30, 45, 60 and 75 DAT (Table 3). At 30 DAT the tallest plant $(47.57 \mathrm{~cm})$ was observed from $\mathrm{N}_{2} \mathrm{P}_{2}$ which was statistically similar to $\mathrm{N}_{2} \mathrm{P}_{1}(44.903 \mathrm{~cm})$ whereas the shortest plant was recorded from $\mathrm{N}_{0} \mathrm{P}_{0}(20.667 \mathrm{~cm})$. At 45 DAT the tallest plant $(64.02 \mathrm{~cm})$ was observed from $\mathrm{N}_{2} \mathrm{P}_{2}$ whereas the shortest plant was recorded from $\mathrm{N}_{0} \mathrm{P}_{0}(34.55 \mathrm{~cm})$. At 60 DAT the tallest plant was observed from $\mathrm{N}_{2} \mathrm{P}_{2}$ $(77.04 \mathrm{~cm})$ which was statistically similar with $\mathrm{N}_{2} \mathrm{P}_{1}(73.73 \mathrm{~cm})$ whereas the shortest plant was recorded from NOP0 $(48.38 \mathrm{~cm})$ which was statistically similar to $\mathrm{N}_{0} \mathrm{P}_{1}(50.41 \mathrm{~cm}), \mathrm{N}_{0} \mathrm{P}_{2}(54.07 \mathrm{~cm}$. At 75 DAT the tallest plant was observed from $\mathrm{N}_{2} \mathrm{P}_{2}(92.90 \mathrm{~cm})$ which was statistically similar to $\mathrm{N}_{2} \mathrm{P}_{1}(86.82 \mathrm{~cm}), \mathrm{N}_{1} \mathrm{P}_{2}(85.82 \mathrm{~cm}), \mathrm{N}_{1} \mathrm{P}_{1}(82.8 \mathrm{~cm}), \mathrm{N}_{1} \mathrm{P}_{2}(82.64$ $\mathrm{cm}), \mathrm{N}_{1} \mathrm{P}_{0}(78.30 \mathrm{~cm})$ whereas the shortest plant was recorded from $\mathrm{N}_{0} \mathrm{P}_{0}$ $(52.29 \mathrm{~cm})$ which was statistically similar to $\mathrm{N}_{0} \mathrm{P}_{1}(55.44 \mathrm{~cm}), \mathrm{N}_{0} \mathrm{P}_{2}(59.63$ $\mathrm{cm}$. Similar results were found by [31]. They stated that among the various $\mathrm{N}$ and P combinations, $120 \mathrm{~kg} \mathrm{~N}+60 \mathrm{~kg}$ P ha- 1 recorded the greatest plant height $(64.83 \mathrm{~cm})$ were also found similar results [12].

Nitrogen fertilizer doses showed a significant effect on the number of leaves per plant of Capsicum at 30, 45, 60 and 75 DAT (Table 4). At 30 DAT the highest number of leaves per plant (67.00) was observed from the $\mathrm{N}_{2}$ treatment which was statistically similar to $\mathrm{N}_{1}$ (54.67) whereas the lowest (42.11) was observed from $\mathrm{N}_{0}$ treatment. At 45 DAT the highest number of leaves per plant (103.11) was observed from the $\mathrm{N}_{2}$ treatment whereas the lowest (54.89) was observed from $\mathrm{N}_{0}$ treatment. At 60 DAT the highest number of leaves per plant was observed from the $\mathrm{N}_{2}(144.000)$ treatment whereas the lowest was observed from $\mathrm{N}_{0}$ (84.333) treatment. At $75 \mathrm{DAT}$ the highest number of leaves per plant was observed from the $\mathrm{N}_{2}(182.44)$ treatment which was statistically similar to $N_{1}(167.22)$ whereas the lowest was observed from $\mathrm{N}_{0}$ (84.33) treatment. As data showed, nitrogen fertilization increased leaf number which was in agreement with findings of [13-14]. The number of leaves per plant of Capsicum varied significantly for different levels $(30,45,65$ and 80 DAT) of phosphorus (Table 4). At 30 DAT the highest number of leaves (58.44) was recorded in $\mathrm{P}_{2}$ which was statistically identical $\mathrm{P}_{1}$ (54.44) whereas the lowest number of leaves was recorded from $\mathrm{P}_{0}$ (50.89). At 45 DAT the highest number of leaves (87.00) was recorded in $\mathrm{P}_{2}$ which was statistically similar to $\mathrm{P}_{1}$ (83.44) whereas the lowest number of leaves was recorded from $\mathrm{P}_{0}$ (79.89). At 60 DAT the highest number of leaves was recorded in $\mathrm{P}_{1}(129.000)$ whereas the lowest number of leaves was recorded from $\mathrm{P}_{0}$ (86.000). At 75 DAT the highest number of leaves (164.78) was recorded in $\mathrm{P}_{2}$ whereas the lowest number of leaves was recorded from $P_{0}$ (157.44). The results showed a significant variation in the number of leaves per plant with increasing phosphorus in $\mathrm{P}_{1}$ treatment up to $\mathrm{P}_{2}$ treatment. The significant combined effect between nitrogen and phosphorus on number of leaves was observed of Capsicum at 30, 45, 60 and $75 \mathrm{DAT}$ (Table 5). At $30 \mathrm{DAT} \mathrm{N}_{2} \mathrm{P}_{2}$ showed the maximum (70.33) number of leaves which was statistically similar to $\mathrm{N}_{2} \mathrm{P}_{1}$ (66.67), $\mathrm{N}_{2} \mathrm{P}_{0}$ (64.00), $\mathrm{N}_{1} \mathrm{P}_{2}$ (59.67) while $\mathrm{N}_{0} \mathrm{P}_{0}$ condition showed the minimum (39.00) number of leaves which was statistically similar to $\mathrm{N}_{0} \mathrm{P}_{1}(42.00)$. At 45 DAT $\mathrm{N}_{2} \mathrm{P}_{2}$ showed the maximum (106.33) number of leaves while $\mathrm{N}_{0} \mathrm{P}_{0}$ condition showed the minimum (51.33) number of leaves which was statistically similar to $\mathrm{N}_{0} \mathrm{P}_{1}$ (55.00). At 60 DAT the maximum (153.67) number of leaves observed in $\mathrm{N}_{2} \mathrm{P}_{2}$ while NOP0 condition showed the minimum (86.89) number of leaves. At 75 DAT $\mathrm{N}_{2} \mathrm{P}_{2}$ showed the maximum (187.67) number of leaves while $\mathrm{N}_{0} \mathrm{P}_{0}$ condition showed the minimum $(131.00)$ number of leaves which was statistically similar to $\mathrm{N}_{0} \mathrm{P}_{1}(136.33)$ and $\mathrm{N}_{0} \mathrm{P}_{3}$ (136.33). The results showed significant variation in the interaction of nitrogen and phosphorus treatments. These results agree with Manchanda and Singh (1988). They concluded that number of the leaf per plant increased with increase fertilizer dose of NP.

Leaf length of Capsicum was statistically influenced by different levels of nitrogen (Table 6). The longest length of leaf $(11.80 \mathrm{~cm})$ was observed from $\mathrm{N}_{2}$ while the shortest length of leaf $(10.457 \mathrm{~cm})$ was found from $\mathrm{N}_{0}$ or control treatment. The increase in leaf area brought by the $\mathrm{N}$ supply causing expansion of individual leaves has also been reported, because $\mathrm{N}$ stimulated the cell division and cell expansion [15-16]. Length of the leaf 
of Capsicum varied significantly for different levels of phosphorus (Table 6). The longest length of leaf $(11.667 \mathrm{~cm})$ was observed from $P_{2}$ which was statistically identical to P3 $(11.00 \mathrm{~cm})$ whereas the shortest length of the leaf was recorded from $\mathrm{P}_{0}(9.63 \mathrm{~cm})$ or control condition. The beneficial effect of phosphorus on the leaf length has been reported by a research in cowpea in groundnut [17-18]. Significant influence was observed on leaf length of Capsicum due to the different doses of nitrogen and phosphorus (Table 7). The longest leaf length $(11.913 \mathrm{~cm})$ was obtained from $\mathrm{N}_{2} \mathrm{P}_{2}$ similar to $\mathrm{N}_{2} \mathrm{P}_{1}, \mathrm{~N}_{2} \mathrm{P}_{0}$, and $\mathrm{N}_{1} \mathrm{P}_{1}$. In contrast to the lowest leaf length 9.55 $\mathrm{cm}$ ) was observed from $\mathrm{N}_{0} \mathrm{P}_{0}$ or control condition.

Leaf breadth of Capsicum was statistically influenced by different doses of nitrogen (Table 6). The highest leaf breadth $(3.87 \mathrm{~cm})$ was observed from $\mathrm{N}_{2}$ which was statistically identical to $\mathrm{N}_{1}(3.52 \mathrm{~cm})$ while the shortest leaf breadth $(3.00 \mathrm{~cm})$ was found from $\mathrm{N}_{0}$ or control condition. A critical observation of the data indicated that leaf breadth increased with increasing levels of nitrogen up to $100 \mathrm{~kg} / \mathrm{ha}$ and then a decreasing trend was observed with an increase in nitrogen levels [19]. The breadth of the leaf of Capsicum varied significantly for different levels of phosphorus (Table 6). The highest leaf breadth $(3.56 \mathrm{~cm})$ was observed from $\mathrm{P}_{2}$ which was statistically identical to $P_{1}(3.39 \mathrm{~cm})$ whereas the shortest length of the leaf was recorded from $\mathrm{P}_{0}(3.26 \mathrm{~cm})$ or control condition. They reported that a linear increase was observed on leaf breadth with the increasing application of phosphorus up to $180 \mathrm{~kg} / \mathrm{ha}$ [20]. Significant influence was observed on leaf length of Capsicum due to the different doses of nitrogen and phosphorus (Table 7). The longest leaf length (4.26 $\mathrm{cm}$ ) was obtained from $\mathrm{N}_{2} \mathrm{P}_{2}$ which was statistically identical to $\mathrm{N}_{2} \mathrm{P}_{1}$ (3.76 $\mathrm{cm}) \& \mathrm{~N}_{2} \mathrm{P}_{0}(3.59 \mathrm{~cm})$. In contrast to the lowest leaf length $(2.95 \mathrm{~cm})$ was observed from $\mathrm{N}_{0} \mathrm{P}_{0}$ or control condition.

The number of branches of Capsicum varied significantly for different levels of nitrogen (Table 6). The maximum number of branches (15.00) was observed from $\mathrm{N}_{2}$ and the minimum number of branches was recorded from $\mathrm{N}_{0}(7.00)$ or control condition. Nitrogen has a significant effect on number of branches per plant as it activates vegetative growth [21]. They concluded that branches per plant increase with the increasing nitrogen rate. The number of branches of Capsicum was statistically influenced by different doses of phosphorus (Table 6). The maximum number of branches was observed from $P_{2}$ (12.22) which was statistically similar to $P_{1}$ (11.11) while the minimum number of branches was found from $\mathrm{P}_{0}$ (8.45) or control condition. Phosphorus had a significant effect on number of branches per plant and increased with the increasing of phosphorus rate. A similar result was found [22]. Significant influence was observed on the number of branches of Capsicum due to the different doses of nitrogen and phosphorus (Table 7). The maximum number of branches (16.33) was obtained from $\mathrm{N}_{2} \mathrm{P}_{2}$ which was statistically identical to $\mathrm{N}_{2} \mathrm{P}_{1}$ (14.67). In contrast to the minimum number of branches (6.00) was observed from $\mathrm{N}_{0} \mathrm{P}_{0}$ or control condition which was statistically identical to $\mathrm{N}_{0} \mathrm{P}_{1}$ (7.00). These results showed that a higher dose of nitrogen and phosphorus was influential nutrients for the number of branches per plant at the final harvesting stage.

\subsection{Effect of nitrogen and phosphorus on yield contributing character of Capsicum}

Significant variation was observed among the different treatments due to different doses of nitrogen in respect of the average fruit length of Capsicum (Table 8). Fruit length was recorded $3.972 \mathrm{~cm}, 4.326 \mathrm{~cm}, 4.827$ $\mathrm{cm}$ in $\mathrm{N}_{0}, \mathrm{~N}_{1}$ and $\mathrm{N}_{2}$ treatments respectively. Maximum $(4.827 \mathrm{~cm})$ fruit length was found in $\mathrm{N}_{2}$ treatment which was statistically similar to $\mathrm{N}_{1}$ $(4.326 \mathrm{~cm})$ treatment whereas minimum fruit length was recorded from $\mathrm{N}_{0}(3.972 \mathrm{~cm})$ or control treatment. The results are to some extent in agreement with who observed an improvement in fruit size with increasing nitrogen application [11]. Significant variation was found among the different treatments due to different doses of phosphorus in respect of fruit length of Capsicum (Table 8). The average fruit length was recorded $4.457 \mathrm{~cm}, 4.392 \mathrm{~cm}$, and $3.776 \mathrm{~cm}$ in $\mathrm{P}_{2}, \mathrm{P}_{1}$, and $\mathrm{P}_{0}$ treatments respectively. However, maximum $(4.457 \mathrm{~cm})$ fruit length was found in $\mathrm{P}_{2}$ treatment whereas minimum fruit length was recorded in $P_{0}(3.776 \mathrm{~cm})$. The combined effect of nitrogen and phosphorus doses showed a significant variation on the fruit diameter of Capsicum (Table 9). Maximum $(4.99 \mathrm{~cm})$ fruit length was recorded in $\mathrm{N}_{2} \mathrm{P}_{2}$ treatment whereas minimum $(3.893 \mathrm{~cm})$ fruit length was recorded in NOP0 or control treatment. These results are similar to that of $[11,23]$. A study obtained the highest yield due to an improvement in fruit size in response to $80 \mathrm{~kg} \mathrm{~N}$ and $90 \mathrm{~kg} P$ [11].

Significant variation was observed among the different treatments due to different doses of nitrogen in respect of the average fruit diameter of Capsicum (Table 8). Fruit diameter was recorded $0.81,0.70$ and $0.67 \mathrm{~cm}$ in $\mathrm{N}_{2}, \mathrm{~N}_{1}$, and $\mathrm{N}_{0}$ treatments respectively. Maximum $(0.81 \mathrm{~cm})$ fruit diameter was found in $\mathrm{N}_{2}$ treatment which was statistically similar to $\mathrm{N}_{1}$
$(0.70 \mathrm{~cm})$ treatment whereas minimum fruit diameter was recorded in $\mathrm{N}_{0}$ $(0.67 \mathrm{~cm})$ or control treatment. A research documented a similar report on the fruit diameter of Capsicum. According to the length and diameter of fruits and nos. fruits per plant increased significantly with increasing nitrogen dose at $\mathrm{N}_{2}$ treatment ( $\left.110 \mathrm{~kg} \mathrm{~N} \mathrm{ha}-{ }^{-1}\right)$. A significant variation was found in the fruit diameter due to the effect of different levels of phosphorus in Capsicum (Table 8). Fruit diameter was recorded 0.69, 0.73 and $0.76 \mathrm{~cm}$ in $\mathrm{P}_{0}, \mathrm{P}_{1}$, and $\mathrm{P}_{2}$ treatments respectively. Maximum $(0.75 \mathrm{~cm})$ fruit diameter was found in $\mathrm{P}_{2}$ treatment which was statistically similar to $\mathrm{P}_{1}(0.73 \mathrm{~cm})$ whereas minimum fruit diameter was recorded in $\mathrm{P}_{0}(0.69$ $\mathrm{cm}$ ) or control treatment. The combined effect of nitrogen and phosphorus doses showed a significant variation on fruit diameter of Capsicum (Table 9). Maximum $(0.84 \mathrm{~cm})$ fruit diameter was recorded in $\mathrm{N}_{2} \mathrm{P}_{2}$ treatment whereas minimum $(0.66 \mathrm{~cm})$ fruit diameter was recorded in $\mathrm{N}_{0} \mathrm{P}_{0}$.

There was a significant variation in single fruit weight among different doses of nitrogen treatments (Table 10). Individual fruit weight was recorded $1.270 \mathrm{gm}, 1.714 \mathrm{gm}$ and $1.912 \mathrm{gm}$ in $\mathrm{N}_{0}, \mathrm{~N}_{1}$, and $\mathrm{N}_{2}$ treatments respectively. The highest individual fruit weight (1.912 gm) was found in $\mathrm{N}_{2}$ treatment whereas the lowest individual fruit weight was found in $\mathrm{N}_{0}$ $(1.27 \mathrm{gm})$ or control treatment. The result showed an increase in nitrogen levels increases the fruit weight. The results were also similar to who also reported that increasing the rate of nitrogen fertilizers increases the average fruit weight and volume of pepper [24]. This result is also in agreement with. There was a significant variation in single fruit weight among different doses of phosphorus treatments (Table 10). Individual fruit weight was recorded 1.384, 1.62 and 1.692 gm in $\mathrm{P}_{0}, \mathrm{P}_{1}$, and $\mathrm{P}_{2}$ treatments respectively. The highest individual fruit weight $(1.692 \mathrm{gm})$ was found in $\mathrm{P}_{2}$ treatment whereas the lowest single fruit weight was found in $\mathrm{P}_{0}(1.384 \mathrm{gm})$ or control treatment. The combined effect of nitrogen and phosphorus doses showed a significant variation on single fruit weight (Table 11). The highest single fruit weight (2.02) was found in $\mathrm{N}_{2} \mathrm{P}_{2}$ treatment whereas the lowest single fruit weight was found in $\mathrm{N}_{0} \mathrm{P}_{0}$ (1.24) or control treatment.

There was a significant variation on the number of fruits per plant among different treatments (Table 10). The highest number of fruits per plant was found in $\mathrm{N}_{2}$ (195.33) treatment whereas the lowest number of fruits per plant was found in $\mathrm{N}_{0}(114.22)$ or control treatment. It was revealed that at optimum level nitrogen fertilizer gave the highest yield plant- ${ }^{1}$ and increase nitrogen fertilization delayed flowering. A study found that flowering was delayed with an increase in nitrogen fertilization due to the diversion of photosynthetic for vegetative growth of the plant [25]. Also found similar results. Significant variation was found among the different treatments due to different doses of phosphorus in respect of the number of fruits per plant (Table 16) [26]. The highest number of fruits per plant was found in $\mathrm{P}_{2}$ (164.78) treatment whereas the lowest number of fruits per plant was found in $P_{0}$ (136.89) or control treatment. An increase in fruits increasing per plant with the increasing levels of phosphorus and the maximum number being at $\mathrm{P}_{2}$ levels in pea [27]. The combined effect of nitrogen and phosphorus doses showed a significant variation on number of fruits per plant (Table 11). The highest number of fruits per plant (200.00) was found in $\mathrm{N}_{2} \mathrm{P}_{2}$ treatment whereas the lowest (111.00) number of fruit per plant was found in $\mathrm{N}_{0} \mathrm{P}_{0}$. The high yield will obtain due to high nitrogen and phosphorus rate. These results agree with the findings who obtained the maximum fruits per plant at a higher rate of nitrogen and phosphorus [21].

The yield of green fresh fruit of Capsicum was recorded 0.458, 0.698 and $0.786 \mathrm{~kg} /$ plot in $\mathrm{N}_{0}, \mathrm{~N}_{1}$, and $\mathrm{N}_{2}$ treatments respectively (Table 10 ). Maximum $(0.786 \mathrm{~kg} / \mathrm{plot})$ yield was obtained in $\mathrm{N}_{2}$ treatment and a minimum $(0.458 \mathrm{~kg} / \mathrm{plot})$ was found in $\mathrm{N}_{0}$ treatment or control treatment. $\mathrm{N}$ fertilization significantly increased fruit number, yield per plant and total yield comparing to control, which were in agreement with reported that nitrogen application @ 100 kg ha-1 significantly increased brinjal yield [28-30]. Likewise, also observed the same results in pea. The yield of fruits of Capsicum was recorded 0.440, 0.647 and $0.665 \mathrm{~kg} / \mathrm{plot}$ in $\mathrm{P}_{0}, \mathrm{P}_{1}$ and $\mathrm{P}_{2}$ treatments respectively (Table 10) [26] [1]. Maximum $(0.665$ $\mathrm{kg} / \mathrm{plot}$ ) yield was obtained in $\mathrm{P}_{2}$ treatment and a minimum ( $\left.0.44 \mathrm{~kg} / \mathrm{plot}\right)$ was found in $\mathrm{P}_{0}$ treatment or control treatment. Significant influence was observed on the yield of Capsicum per plot due to the different doses of nitrogen and phosphorus (Table 11). The maximum yield of $0.807 \mathrm{~kg} / \mathrm{plot}$ was obtained from $\mathrm{N}_{2} \mathrm{P}_{2}$. In contrast to the minimum $(0.328 \mathrm{~kg} / \mathrm{plot})$ was observed from $\mathrm{N}_{0} \mathrm{P}_{0}$ or control condition. The result was similar to that of $[11,23]$. Obtained the highest yield due to an improvement in fruit size in response to $100 \mathrm{~kg} \mathrm{~N}, 80 \mathrm{~kg} \mathrm{P}\left(\mathrm{N}_{2} \mathrm{P}_{2}\right)$. It means that the recommended fertilization may affect the fruit size and other growth parameters as well [11].

The yield of green fresh fruit of Capsicum was recorded 3.82, 5.82 and 6.57 ton/ha in $\mathrm{N}_{0}, \mathrm{~N}_{1}$ and $\mathrm{N}_{2}$ treatments respectively (Table 10). A maximum (6.57 ton/ha) yield was obtained in $\mathrm{N}_{2}$ treatment and a minimum $(3.82$ 
ton/ha) was found in $\mathrm{N}_{0}$ treatment or control treatment. Nitrogen fertilization improved plant growth but did not influence fruiting time. Reported that nitrogen application @ 110-130 kg ha-1 significantly increased brinjal yield [30]. In pea, also found the same results [27]. The yield of fruits of Capsicum was recorded 4.25, 5.39 and 5.56 ton/ha in $\mathrm{P}_{0}$, $\mathrm{P}_{1}$ and $\mathrm{P}_{2}$ treatments respectively (Table 10). A maximum (5.564 ton/ha) yield was obtained in $\mathrm{P}_{3}$ treatment and a minimum (4.25 ton/ha) was found in $\mathrm{P}_{0}$ treatment or control treatment. Significant influence was observed on the yield of Capsicum per plot due to the different doses of nitrogen and phosphorus (Table 11). The maximum yield of 6.79 tons/ha was obtained from $\mathrm{N}_{2} \mathrm{P}_{2}$. In contrast to the minimum (2.67 ton/ha) was observed from $\mathrm{N}_{0} \mathrm{P}_{0}$ or control condition. These results are in accordance with the findings of who assessed the growth and yield performance of hot pepper varieties to various doses of nitrogen and phosphorous [31]. Reported that different doses of nitrogen and phosphorus behaved significantly different for total yield [32]. Besides the sun beating down on the roof, there is ambient heat being reflected from the roof surface, surrounding buildings, streetcars and metal exhaust and utility structures [33]. The higher temperature greatly reduced the yield of Capsicum because of the lack of moisture content in the soil. But in agricultural field condition, the frequent irrigation facilitate to maintain the moisture content as well as maintain the soil temperature which increases the yield performance of Capsicum.

\subsection{Comparison of total yield of chili in rooftop garden to agricultural field}

Capsicum annuum, an important spice and vegetable crop of Bangladesh is widely grown both in winter and summer seasons. The area under chili cultivation was 93.55 thousand hectares producing about 102.25 thousand tons in the year 2015-16 (BBS 2015). In field condition, average yield should be gained around 10-12 ton/ha and the average plant height is around 75-85 cm (Krishi Projockti Hathboi-7th edition-2017). But in the rooftop garden, the highest yield obtained from $\mathrm{N}_{2} \mathrm{P}_{2}$ treatment which is 6.787 tons/ha and the lower production obtained from $\mathrm{N}_{0} \mathrm{P}_{0}$ treatment which is around 2.67 tons/ha. Average highest soil temperature $\left(32.98{ }^{0}\right.$ C) was recorded from $\mathrm{N}_{0} \mathrm{P}_{0}$ treatment which create negative effect on chili production. The lowest soil temperature was recorded from $\mathrm{N}_{2} \mathrm{P}_{1}$ treatment $\left(27.12{ }^{\circ} \mathrm{C}\right)$ which increase chili yield. The highest moisture was recorded $34.44 \mathrm{~N}_{2} \mathrm{P}_{0}$ and the lowest moisture was recorded $28.09 \%$ in $\mathrm{N}_{0} \mathrm{P}_{0}$ (control) treatment. The highest light intensity was observed (34.59 flux) from $\mathrm{N}_{1} \mathrm{P}_{2}$ treatment whereas the lowest light intensity was recorded (30.79 flux) from $\mathrm{N}_{0} \mathrm{P}_{1}$ treatment. Due to the lack of soil moisture and light availability the yield of chili in roof top garden were lower than field condition. Temperature also play a significant role in rooftop farming. In roof top garden, the temperature always higher than normal field condition which greatly influence on morphology and yield of chili. Wind can whip down straight urban streets, especially on high-rises. That's why flower and fruit dropped at a high extent than normal field conditions and the fruit number greatly reduced by the interaction of high wind.

Table 2: The effect of different levels of nitrogen and phosphorous on plant height of Capsicum

\begin{tabular}{|l|l|l|l|l|}
\hline \multirow{2}{*}{ Treatment } & \multicolumn{4}{|l|}{ Plant Height (cm) } \\
\cline { 2 - 5 } & 30 DAT & 45 DAT & 60 DAT & 75 DAT \\
\hline Levels of Nitrogen \\
\hline $\mathbf{N}_{\mathbf{0}}$ & $23.091 \mathrm{c}$ & $37.977 \mathrm{c}$ & $50.953 \mathrm{~b}$ & $55.784 \mathrm{~b}$ \\
\hline $\mathbf{N}_{\mathbf{1}}$ & $37.329 \mathrm{~b}$ & $50.113 \mathrm{~b}$ & $67.140 \mathrm{a}$ & $82.309 \mathrm{a}$ \\
\hline $\mathbf{N}_{\mathbf{2}}$ & $44.798 \mathrm{a}$ & $59.906 \mathrm{a}$ & $74.439 \mathrm{a}$ & $87.454 \mathrm{a}$ \\
\hline \multicolumn{5}{|l}{} \\
\hline Levels of Phosphorus \\
\hline $\mathbf{P}_{\mathbf{0}}$ & $32.393 \mathrm{~b}$ & $45.686 \mathrm{~b}$ & $61.263 \mathrm{~b}$ & $71.077 \mathrm{~b}$ \\
\hline $\mathbf{P}_{\mathbf{1}}$ & $35.589 \mathrm{ab}$ & $49.653 \mathrm{ab}$ & $64.269 \mathrm{a}$ & $75.021 \mathrm{ab}$ \\
\hline $\mathbf{P}_{\mathbf{2}}$ & $37.236 \mathrm{a}$ & $52.657 \mathrm{a}$ & $67.000 \mathrm{a}$ & $79.450 \mathrm{a}$ \\
\hline $\mathbf{L S D}(\mathbf{0 . 0 1})$ & 6.040 & 5.857 & 7.477 & 7.589 \\
\hline CV\% & $7.22 \%$ & $4.98 \%$ & $4.89 \%$ & $4.23 \%$ \\
\hline
\end{tabular}

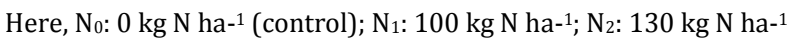

$\mathrm{P}_{0}: 0$ kg $\mathrm{P}_{2} \mathrm{O}_{5}$ ha-1 (control); $\mathrm{P}_{1}: 50 \mathrm{~kg} \mathrm{P}_{2} \mathrm{O}_{5}$ ha- $^{-1} ; \mathrm{P}_{2}: 80$ kg P$_{2} \mathrm{O}_{5}$ ha-1

Table 3: The combined effect of different levels of nitrogen and phosphorous on plant height of Capsicum

\section{\begin{tabular}{l|l} 
Treatment & Plant Height $(\mathrm{cm})$ \\
\hline
\end{tabular}}

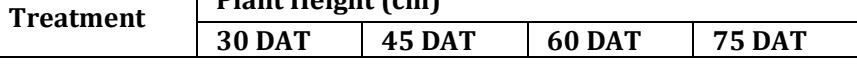

\begin{tabular}{|l|l|l|l|l|}
\hline \multicolumn{5}{|c|}{} \\
\hline $\mathbf{N}_{\mathbf{0}} \mathbf{P}_{\mathbf{0}}$ & $20.667^{\mathrm{g}}$ & $34.550^{\mathrm{g}}$ & $48.380^{\mathrm{f}}$ & $52.287^{\mathrm{e}}$ \\
\hline $\mathbf{N}_{\mathbf{0}} \mathbf{P}_{\mathbf{1}}$ & $24.830^{\mathrm{f}}$ & $38.453^{\mathrm{f}}$ & $50.410^{\mathrm{ef}}$ & $55.440^{\mathrm{de}}$ \\
\hline $\mathbf{N}_{\mathbf{0}} \mathbf{P}_{2}$ & $23.777^{\mathrm{fg}}$ & $40.927^{\mathrm{f}}$ & $54.070^{\mathrm{e}}$ & $59.627^{\mathrm{d}}$ \\
\hline $\mathbf{N}_{\mathbf{1}} \mathbf{P}_{\mathbf{0}}$ & $34.597^{\mathrm{e}}$ & $46.437^{\mathrm{e}}$ & $62.863^{\mathrm{d}}$ & $78.303^{\mathrm{c}}$ \\
\hline $\mathbf{N}_{\mathbf{1}} \mathbf{P}_{\mathbf{1}}$ & $37.033^{\mathrm{de}}$ & $50.877^{\mathrm{d}}$ & $68.663^{\mathrm{c}}$ & $82.803^{\mathrm{bc}}$ \\
\hline $\mathbf{N}_{\mathbf{1}} \mathbf{P}_{2}$ & $40.357^{\mathrm{cd}}$ & $53.027^{\mathrm{cd}}$ & $69.893^{\mathrm{bc}}$ & $85.820^{\mathrm{b}}$ \\
\hline $\mathbf{N}_{2} \mathbf{P}_{\mathbf{0}}$ & $41.917^{\mathrm{bc}}$ & $56.070^{\mathrm{c}}$ & $72.547^{\mathrm{abc}}$ & $82.640^{\mathrm{bc}}$ \\
\hline $\mathbf{N}_{\mathbf{2}} \mathbf{P}_{\mathbf{1}}$ & $44.903^{\mathrm{ab}}$ & $59.630^{\mathrm{b}}$ & $73.733^{\mathrm{ab}}$ & $86.820^{\mathrm{b}}$ \\
\hline $\mathbf{N}_{\mathbf{2}} \mathbf{P}_{\mathbf{2}}$ & $47.573^{\mathrm{a}}$ & $64.017^{\mathrm{a}}$ & $77.037^{\mathrm{a}}$ & $92.903^{\mathrm{a}}$ \\
\hline $\mathbf{L S D}(\mathbf{0 . 0 1})$ & 3.487 & 3.382 & 4.317 & 4.381 \\
\hline $\mathbf{C V} \%$ & $7.22 \%$ & $4.98 \%$ & $4.89 \%$ & $4.23 \%$ \\
\hline
\end{tabular}

Here, $\mathrm{N}_{0}: 0$ kg N ha- ${ }^{-1}$ (control); $\mathrm{N}_{1}: 100 \mathrm{~kg} \mathrm{~N}^{-1}{ }^{-1} \mathrm{~N}_{2}: 130 \mathrm{~kg} \mathrm{~N}^{-1}$

$\mathrm{P}_{0}: 0$ kg $\mathrm{P}_{2} \mathrm{O}_{5}$ ha- ${ }^{-1}$ (control); $\mathrm{P}_{1}: 50$ kg $\mathrm{P}_{2} \mathrm{O}_{5}$ ha- ${ }^{-1}$; $\mathrm{P}_{2}: 80$ kg $\mathrm{P}_{2} \mathrm{O}_{5}$ ha- ${ }^{1}$

Table 4: The effect of different levels of nitrogen and phosphorous on number of leaves plant- 1 of Capsicum

\begin{tabular}{|c|c|c|c|c|}
\hline \multirow{2}{*}{ Treatment } & \multicolumn{4}{|c|}{ Number of Leaves Plant-1 } \\
\hline & 30 DAT & 45 DAT & 60 DAT & 75 DAT \\
\hline \multicolumn{5}{|c|}{ Levels of Nitrogen } \\
\hline $\mathbf{N}_{\mathbf{0}}$ & $42.111 \mathrm{c}$ & $54.889 \mathrm{c}$ & $84.333 \mathrm{c}$ & $135.444 \mathrm{c}$ \\
\hline $\mathbf{N}_{1}$ & $54.667 \mathrm{~b}$ & $92.333 \mathrm{~b}$ & $129.667 \mathrm{~b}$ & $167.222 \mathrm{~b}$ \\
\hline $\mathbf{N}_{2}$ & $67.000 \mathrm{a}$ & $103.111 \mathrm{a}$ & $144.000 \mathrm{a}$ & $182.444 \mathrm{a}$ \\
\hline \multicolumn{5}{|c|}{ Levels of Phosphorus } \\
\hline $\mathbf{P}_{0}$ & $50.889 \mathrm{c}$ & $79.889 \mathrm{~b}$ & $86.000 \mathrm{~b}$ & $157.444 \mathrm{a}$ \\
\hline $\mathbf{P}_{1}$ & $54.444 \mathrm{~b}$ & $83.444 \mathrm{ab}$ & $129.000 \mathrm{ab}$ & $162.889 \mathrm{a}$ \\
\hline $\mathbf{P}_{2}$ & $58.444 \mathrm{a}$ & $87.000 \mathrm{a}$ & $121.333 \mathrm{a}$ & $164.778 \mathrm{a}$ \\
\hline LSD (0.01) & 3.273 & 4.811 & 5.172 & 9.307 \\
\hline CV\% & $2.51 \%$ & $2.42 \%$ & $1.75 \%$ & $2.41 \%$ \\
\hline
\end{tabular}

Here, $\mathrm{N}_{0}: 0$ kg N ha- ${ }^{-1}$ (control); $\mathrm{N}_{1}: 100 \mathrm{~kg} \mathrm{~N}^{-1}{ }^{-1} ; \mathrm{N}_{2}: 130 \mathrm{~kg} \mathrm{~N}^{-1}$

$\mathrm{P}_{0}: 0$ kg $\mathrm{P}_{2} \mathrm{O}_{5}$ ha- ${ }^{-1}$ (control); $\mathrm{P}_{1}: 50$ kg $\mathrm{P}_{2} \mathrm{O}_{5}$ ha- ${ }^{-1} ; \mathrm{P}_{2}: 80$ kg $_{2} \mathrm{O}_{5}$ ha-1

Table 5: The combined effect of different levels of nitrogen and phosphorous on number of leaves plant- 1 of Capsicum

\begin{tabular}{|l|l|l|l|l|}
\hline \multirow{2}{*}{ Treatment } & \multicolumn{4}{|l|}{ Plant Height (cm) } \\
\cline { 2 - 5 } & 30 DAT & 45 DAT & 60 DAT & 75 DAT \\
\hline $\mathbf{N}_{\mathbf{0}} \mathbf{P}_{\mathbf{0}}$ & $39.000 \mathrm{i}$ & $51.333 \mathrm{i}$ & $86.889 \mathrm{i}$ & $131.000 \mathrm{e}$ \\
\hline $\mathbf{N}_{\mathbf{0}} \mathbf{P}_{\mathbf{1}}$ & $42.000 \mathrm{~h}$ & $55.000 \mathrm{~h}$ & $87.000 \mathrm{~h}$ & $136.333 \mathrm{de}$ \\
\hline $\mathbf{N}_{\mathbf{0}} \mathbf{P}_{\mathbf{2}}$ & $45.333 \mathrm{~g}$ & $58.333 \mathrm{~g}$ & $90.333 \mathrm{~g}$ & $139.000 \mathrm{~d}$ \\
\hline $\mathbf{N}_{\mathbf{1}} \mathbf{P}_{\mathbf{0}}$ & $49.667 \mathrm{f}$ & $88.333 \mathrm{f}$ & $131.000 \mathrm{f}$ & $165.000 \mathrm{c}$ \\
\hline $\mathbf{N}_{\mathbf{1}} \mathbf{P}_{\mathbf{1}}$ & $54.667 \mathrm{e}$ & $92.333 \mathrm{e}$ & $135.333 \mathrm{e}$ & $169.000 \mathrm{c}$ \\
\hline $\mathbf{N}_{\mathbf{1}} \mathbf{P}_{\mathbf{2}}$ & $59.667 \mathrm{~d}$ & $96.333 \mathrm{~d}$ & $140.333 \mathrm{~d}$ & $167.667 \mathrm{c}$ \\
\hline $\mathbf{N}_{\mathbf{2}} \mathbf{P}_{\mathbf{0}}$ & $64.000 \mathrm{c}$ & $100.000 \mathrm{c}$ & $143.667 \mathrm{c}$ & $176.333 \mathrm{~b}$ \\
\hline $\mathbf{N}_{\mathbf{2}} \mathbf{P}_{\mathbf{1}}$ & $66.667 \mathrm{~b}$ & $103.000 \mathrm{~b}$ & $149.000 \mathrm{~b}$ & $183.333 \mathrm{a}$ \\
\hline $\mathbf{N}_{\mathbf{2}} \mathbf{P}_{\mathbf{2}}$ & $70.333 \mathrm{a}$ & $106.333 \mathrm{a}$ & $153.667 \mathrm{a}$ & $187.667 \mathrm{a}$ \\
\hline $\mathbf{L S D}(\mathbf{0 . 0 1})$ & 1.890 & 2.777 & 2.986 & 5.373 \\
\hline $\mathbf{C V} \%$ & $2.51 \%$ & $2.42 \%$ & $1.75 \%$ & $2.41 \%$ \\
\hline
\end{tabular}

Here, $\mathrm{N}_{0}: 0$ kg N ha- ${ }^{-1}$ (control); $\mathrm{N}_{1}: 100 \mathrm{~kg} \mathrm{~N} \mathrm{ha}^{-1} ; \mathrm{N}_{2}: 130 \mathrm{~kg} \mathrm{~N}^{-1}$

$\mathrm{P}_{0}: 0$ kg $\mathrm{P}_{2} \mathrm{O}_{5}$ ha- ${ }^{-1}$ (control); $\mathrm{P}_{1}: 50 \mathrm{~kg} \mathrm{P}_{2} \mathrm{O}_{5}$ ha- ${ }^{-1}$; $\mathrm{P}_{2}: 80$ kg $\mathrm{P}_{2} \mathrm{O}_{5}$ ha- ${ }^{-1}$

Table 6: The effect of different levels of nitrogen and phosphorous on morphological parameters of Capsicum

\begin{tabular}{|l|l|l|l|}
\hline Treatment & $\begin{array}{l}\text { Leaf Length } \\
\text { (cm) }\end{array}$ & $\begin{array}{l}\text { Leaf Breadth } \\
\text { (cm) }\end{array}$ & $\begin{array}{l}\text { Number of } \\
\text { Branches } \\
\text { Plant-1 (cm) }\end{array}$ \\
\hline \multicolumn{4}{|l|}{} \\
\hline $\mathbf{N}_{\mathbf{0}}$ & $9.662 \mathrm{~b}$ & $3.000 \mathrm{~b}$ & $7.000 \mathrm{c}$ \\
\hline $\mathbf{N}_{\mathbf{1}}$ & $11.663 \mathrm{a}$ & $3.322 \mathrm{~b}$ & $11.222 \mathrm{~b}$ \\
\hline $\mathbf{N}_{\mathbf{2}}$ & $11.540 \mathrm{a}$ & $3.871 \mathrm{a}$ & $15.000 \mathrm{a}$ \\
\hline Levels of Phosphorus \\
\hline $\mathbf{P}_{\mathbf{0}}$ & $10.896 \mathrm{a}$ & $3.260 \mathrm{a}$ & $9.889 \mathrm{a}$ \\
\hline $\mathbf{P}_{\mathbf{1}}$ & $10.880 \mathrm{a}$ & $3.394 \mathrm{a}$ & $11.111 \mathrm{a}$ \\
\hline $\mathbf{P}_{\mathbf{2}}$ & $11.090 \mathrm{a}$ & $3.562 \mathrm{a}$ & $12.222 \mathrm{a}$ \\
\hline LSD (0.01) & 1.232 & 0.328 & 2.508 \\
\hline CV\% & $4.72 \%$ & $4.09 \%$ & $9.50 \%$ \\
\hline
\end{tabular}

Here, $\mathrm{N}_{0}: 0$ kg N ha- ${ }^{-1}$ (control); $\mathrm{N}_{1}: 100 \mathrm{~kg} \mathrm{~N}^{-1}{ }^{-1} ; \mathrm{N}_{2}: 130 \mathrm{~kg} \mathrm{~N}^{-1}$

$\mathrm{P}_{0}$ : 0 kg $\mathrm{P}_{2} \mathrm{O}_{5}$ ha- ${ }^{-1}$ (control); $\mathrm{P}_{1}: 50 \mathrm{~kg} \mathrm{P}_{2} \mathrm{O}_{5}$ ha $^{-1}$; $\mathrm{P}_{2}: 80$ kg $\mathrm{P}_{2} \mathrm{O}_{5}$ ha- ${ }^{-1}$

Table 7: The combined effect of different levels of nitrogen and phosphorous on morphological parameters of Capsicum 


\begin{tabular}{|l|l|l|l|}
\hline Treatment & $\begin{array}{l}\text { Leaf Length } \\
\text { (cm) }\end{array}$ & $\begin{array}{l}\text { Leaf Breadth } \\
\text { (cm) }\end{array}$ & $\begin{array}{l}\text { Number of } \\
\text { Branches } \\
\text { Plant-1 }\end{array}$ \\
\hline $\mathbf{N}_{\mathbf{0}} \mathbf{P}_{\mathbf{0}}$ & $9.550 \mathrm{~b}$ & $2.953 \mathrm{f}$ & $6.000 \mathrm{~g}$ \\
\hline $\mathbf{N}_{\mathbf{0}} \mathbf{P}_{\mathbf{1}}$ & $9.750 \mathrm{~b}$ & $3.143 \mathrm{ef}$ & $7.000 \mathrm{fg}$ \\
\hline $\mathbf{N}_{\mathbf{0}} \mathbf{P}_{\mathbf{2}}$ & $9.687 \mathrm{~b}$ & $2.973 \mathrm{f}$ & $8.000 \mathrm{f}$ \\
\hline $\mathbf{N}_{\mathbf{1}} \mathbf{P}_{\mathbf{0}}$ & $11.777 \mathrm{a}$ & $3.233 \mathrm{e}$ & $10.000 \mathrm{e}$ \\
\hline $\mathbf{N}_{\mathbf{1}} \mathbf{P}_{\mathbf{1}}$ & $11.543 \mathrm{a}$ & $3.280 \mathrm{de}$ & $11.333 \mathrm{de}$ \\
\hline $\mathbf{N}_{\mathbf{1}} \mathbf{P}_{\mathbf{2}}$ & $11.670 \mathrm{a}$ & $3.453 \mathrm{~cd}$ & $12.333 \mathrm{~cd}$ \\
\hline $\mathbf{N}_{\mathbf{2}} \mathbf{P}_{\mathbf{0}}$ & $11.360 \mathrm{a}$ & $3.593 \mathrm{bc}$ & $13.667 \mathrm{bc}$ \\
\hline $\mathbf{N}_{\mathbf{2}} \mathbf{P}_{\mathbf{1}}$ & $11.347 \mathrm{a}$ & $3.760 \mathrm{~b}$ & $15.000 \mathrm{ab}$ \\
\hline $\mathbf{N}_{\mathbf{2}} \mathbf{P}_{\mathbf{2}}$ & $11.913 \mathrm{a}$ & $4.260 \mathrm{a}$ & $16.333 \mathrm{a}$ \\
\hline $\mathbf{L S D}(\mathbf{0 . 0 1})$ & 0.7115 & 0.1898 & 1.448 \\
\hline $\mathbf{C V} \mathbf{0}$ & $4.72 \%$ & $4.09 \%$ & $9.50 \%$ \\
\hline
\end{tabular}

Here, $\mathrm{N}_{0}: 0$ kg N ha- ${ }^{-1}$ (control); $\mathrm{N}_{1}: 100 \mathrm{~kg} \mathrm{~N}$ ha- ${ }^{-1} ; \mathrm{N}_{2}: 130 \mathrm{~kg} \mathrm{~N}$ ha- $^{-1}$

$\mathrm{P}_{0}: 0$ kg $\mathrm{P}_{2} \mathrm{O}_{5}$ ha-1 (control); $\mathrm{P}_{1}: 50 \mathrm{~kg} \mathrm{P}_{2} \mathrm{O}_{5}$ ha- ${ }^{-1} ; \mathrm{P}_{2}: 80$ kg $\mathrm{P}_{2} \mathrm{O}_{5}$ ha-1

Table 8: The effect of different levels of nitrogen and phosphorous on yield contributing parameters of Capsicum

\begin{tabular}{|l|l|l|}
\hline Treatment & Fruit Length (cm) & $\begin{array}{l}\text { Fruit } \\
\text { (cm) }\end{array}$ \\
\hline \multicolumn{2}{|l|}{ Levels of Nitrogen } \\
\hline $\mathbf{N}_{\mathbf{0}}$ & $3.972 \mathrm{c}$ & $0.673 \mathrm{~b}$ \\
\hline $\mathbf{N}_{\mathbf{1}}$ & $4.326 \mathrm{~b}$ & $0.697 \mathrm{~b}$ \\
\hline $\mathbf{N}_{\mathbf{2}}$ & $4.827 \mathrm{a}$ & $0.812 \mathrm{a}$ \\
\hline Levels of Phosphorus & \multicolumn{2}{|l}{} \\
\hline $\mathbf{P}_{\mathbf{0}}$ & $4.276 \mathrm{a}$ & $0.706 \mathrm{a}$ \\
\hline $\mathbf{P}_{\mathbf{1}}$ & $4.392 \mathrm{a}$ & $0.726 \mathrm{a}$ \\
\hline $\mathbf{P}_{\mathbf{2}}$ & $4.457 \mathrm{a}$ & $0.751 \mathrm{a}$ \\
\hline $\mathbf{L S D}(\mathbf{0 . 0 1})$ & 0.2719 & 0.07541 \\
$\mathbf{C V} \%$ & $2.62 \%$ & $5.65 \%$ \\
\hline
\end{tabular}

Here, $\mathrm{N}_{0}: 0$ kg N ha- ${ }^{-1}$ (control); $\mathrm{N}_{1}: 100$ kg N ha- ${ }^{-1}$; $\mathrm{N}_{2}: 130 \mathrm{~kg} \mathrm{~N}$ ha- ${ }^{-1}$

$\mathrm{P}_{0}: 0$ kg $\mathrm{P}_{2} \mathrm{O}_{5}$ ha- ${ }^{-1}$ (control); $\mathrm{P}_{1}: 50$ kg $\mathrm{P}_{2} \mathrm{O}_{5}$ ha- ${ }^{-1}$; $\mathrm{P}_{2}: 80$ kg $\mathrm{P}_{2} \mathrm{O}_{5}$ ha-1

Table 9: The combined effect of different levels of nitrogen and phosphorous on yield contributing parameters of Capsicum

\begin{tabular}{|l|l|l|}
\hline Treatment & Fruit Length (cm) & $\begin{array}{l}\text { Fruit Diameter } \\
\text { (cm) }\end{array}$ \\
\hline $\mathbf{N}_{\mathbf{0}} \mathbf{P}_{\mathbf{0}}$ & $3.893 \mathrm{e}$ & $0.657 \mathrm{~d}$ \\
\hline $\mathbf{N}_{\mathbf{0}} \mathbf{P}_{\mathbf{1}}$ & $4.057 \mathrm{e}$ & $0.663 \mathrm{~d}$ \\
\hline $\mathbf{N}_{\mathbf{0}} \mathbf{P}_{\mathbf{2}}$ & $3.967 \mathrm{e}$ & $0.700 \mathrm{~cd}$ \\
\hline $\mathbf{N}_{\mathbf{1}} \mathbf{P}_{\mathbf{0}}$ & $4.223 \mathrm{~d}$ & $0.673 \mathrm{~cd}$ \\
\hline $\mathbf{N}_{\mathbf{1}} \mathbf{P}_{\mathbf{1}}$ & $4.340 \mathrm{~cd}$ & $0.703 \mathrm{~cd}$ \\
\hline $\mathbf{N}_{\mathbf{1}} \mathbf{P}_{\mathbf{2}}$ & $4.413 \mathrm{c}$ & $0.713 \mathrm{c}$ \\
\hline $\mathbf{N}_{\mathbf{2}} \mathbf{P}_{\mathbf{0}}$ & $4.710 \mathrm{~b}$ & $0.787 \mathrm{~b}$ \\
\hline $\mathbf{N}_{\mathbf{2}} \mathbf{P}_{\mathbf{1}}$ & $4.780 \mathrm{~b}$ & $0.810 \mathrm{ab}$ \\
\hline $\mathbf{N}_{\mathbf{2}} \mathbf{P}_{\mathbf{2}}$ & $4.990 \mathrm{a}$ & $0.840 \mathrm{a}$ \\
\hline $\mathbf{L S D} \mathbf{0 . 0 1 )}$ & 0.1570 & 0.04354 \\
\hline $\mathbf{C V} \%$ & $2.62 \%$ & $5.29 \%$ \\
\hline
\end{tabular}

Here, No: 0 kg N ha- ${ }^{-1}$ (control); $\mathrm{N}_{1}: 100$ kg N ha- ${ }^{-1} ; \mathrm{N}_{2}: 130 \mathrm{~kg} \mathrm{~N} \mathrm{ha}^{-1}$

$\mathrm{P}_{0}: 0$ kg $\mathrm{P}_{2} \mathrm{O}_{5}$ ha- ${ }^{1}$ (control); $\mathrm{P}_{1}: 50$ kg $\mathrm{P}_{2} \mathrm{O}_{5}$ ha- ${ }^{1} ; \mathrm{P}_{2}: 80$ kg $\mathrm{P}_{2} \mathrm{O}_{5}$ ha- ${ }^{-1}$

Table 10: The effect of different levels of nitrogen and phosphorous on yield contributing parameters of Capsicum

\begin{tabular}{|l|l|l|l|l|}
\hline Treatment & $\begin{array}{l}\text { Individual } \\
\text { Fruit } \\
\text { Weight } \mathbf{( g )}\end{array}$ & $\begin{array}{l}\text { Yield } \\
\text { Plant-1 } \\
\text { (gm) }\end{array}$ & $\begin{array}{l}\text { Yield } \\
\text { Plot-1 } \\
\text { (kg) }\end{array}$ & $\begin{array}{l}\text { Yield } \\
\text { ha-1 } \\
\text { (ton) }\end{array}$ \\
\hline Levels of Nitrogen & $1.270 \mathrm{c}$ & $114.222 \mathrm{c}$ & $0.458 \mathrm{c}$ & $3.818 \mathrm{c}$ \\
\hline $\mathbf{N}_{\mathbf{0}}$ & $1.714 \mathrm{~b}$ & $172.667 \mathrm{~b}$ & $0.698 \mathrm{~b}$ & $5.820 \mathrm{~b}$ \\
\hline $\mathbf{N}_{\mathbf{1}}$ & $1.912 \mathrm{a}$ & $195.333 \mathrm{a}$ & $0.786 \mathrm{a}$ & $6.571 \mathrm{a}$ \\
\hline $\mathbf{N}_{\mathbf{2}}$ &
\end{tabular}

\begin{tabular}{|l|l|l|l|l|}
\hline \multicolumn{5}{|l|}{ Levels of Phosphorus } \\
\hline $\mathbf{P}_{\mathbf{0}}$ & $1.584 \mathrm{~b}$ & $156.889 \mathrm{~b}$ & $0.630 \mathrm{~b}$ & $5.250 \mathrm{~b}$ \\
\hline $\mathbf{P}_{\mathbf{1}}$ & $1.620 \mathrm{a}$ & $\begin{array}{l}160.556 \\
\mathrm{ab}\end{array}$ & $0.647 \mathrm{ab}$ & $5.394 \mathrm{ab}$ \\
\hline $\mathbf{P}_{2}$ & $1.692 \mathrm{a}$ & $164.778 \mathrm{a}$ & $0.665 \mathrm{a}$ & $5.564 \mathrm{a}$ \\
\hline $\mathbf{L S D}(\mathbf{0 . 0 1})$ & 0.1306 & 4.985 & 0.1847 & \\
\hline CV\% & $3.28 \%$ & $2.41 \%$ & $2.41 \%$ & $2.41 \%$ \\
\hline
\end{tabular}

Here, $\mathrm{N}_{0}: 0$ kg N ha- ${ }^{-1}$ (control); $\mathrm{N}_{1}: 100 \mathrm{~kg} \mathrm{~N} \mathrm{ha}^{-1} ; \mathrm{N}_{2}: 130 \mathrm{~kg} \mathrm{~N}^{-1}$

$\mathrm{P}_{0}$ : 0 kg $\mathrm{P}_{2} \mathrm{O}_{5}$ ha- $^{-1}$ (control); $\mathrm{P}_{1}: 50 \mathrm{~kg} \mathrm{P}_{2} \mathrm{O}_{5}$ ha- $^{-1} ; \mathrm{P}_{2}: 80 \mathrm{~kg} \mathrm{P}_{2} \mathrm{O}_{5}$ ha- $^{-1}$

Table 11: The combined effect of different levels of nitrogen and phosphorous on yield contributing parameters of Capsicum

\begin{tabular}{|l|l|l|l|l|}
\hline Treatment & $\begin{array}{l}\text { Individual } \\
\text { Fruit } \\
\text { Weight (g) }\end{array}$ & $\begin{array}{l}\text { Yield } \\
\text { Plant-1 } \\
\text { (gm) }\end{array}$ & $\begin{array}{l}\text { Yield } \\
\text { Plot-1 } \\
\text { (kg) }\end{array}$ & $\begin{array}{l}\text { Yield ha- } \\
\text { 1 (ton) }\end{array}$ \\
\hline $\mathbf{N}_{\mathbf{0}} \mathbf{P}_{\mathbf{0}}$ & $1.240 \mathrm{e}$ & $111.000 \mathrm{~h}$ & $0.328 \mathrm{~h}$ & $2.667 \mathrm{~h}$ \\
\hline $\mathbf{N}_{\mathbf{0}} \mathbf{P}_{\mathbf{1}}$ & $1.267 \mathrm{e}$ & $114.333 \mathrm{~g}$ & $0.450 \mathrm{~g}$ & $3.833 \mathrm{~g}$ \\
\hline $\mathbf{N}_{\mathbf{0}} \mathbf{P}_{\mathbf{2}}$ & $1.303 \mathrm{e}$ & $117.333 \mathrm{f}$ & $0.473 \mathrm{f}$ & $4.025 \mathrm{f}$ \\
\hline $\mathbf{N}_{\mathbf{1}} \mathbf{P}_{\mathbf{0}}$ & $1.670 \mathrm{~d}$ & $168.000 \mathrm{e}$ & $0.680 \mathrm{e}$ & $5.667 \mathrm{e}$ \\
\hline $\mathbf{N}_{\mathbf{1}} \mathbf{P}_{\mathbf{1}}$ & $1.720 \mathrm{~cd}$ & $173.000 \mathrm{~d}$ & $0.700 \mathrm{~d}$ & $5.840 \mathrm{~d}$ \\
\hline $\mathbf{N}_{\mathbf{1}} \mathbf{P}_{\mathbf{2}}$ & $1.753 \mathrm{c}$ & $177.000 \mathrm{c}$ & $0.714 \mathrm{c}$ & $5.953 \mathrm{c}$ \\
\hline $\mathbf{N}_{\mathbf{2}} \mathbf{P}_{\mathbf{0}}$ & $1.843 \mathrm{~b}$ & $191.667 \mathrm{~b}$ & $0.770 \mathrm{~b}$ & $6.417 \mathrm{~b}$ \\
\hline $\mathbf{N}_{\mathbf{2}} \mathbf{P}_{\mathbf{1}}$ & $1.873 \mathrm{~b}$ & $194.333 \mathrm{~b}$ & $0.780 \mathrm{~b}$ & $6.510 \mathrm{~b}$ \\
\hline $\mathbf{N}_{\mathbf{2}} \mathbf{P}_{\mathbf{2}}$ & $2.020 \mathrm{a}$ & $200.000 \mathrm{a}$ & $0.807 \mathrm{a}$ & $6.787 \mathrm{a}$ \\
\hline $\mathbf{L S D} \mathbf{0 . 0 1 )}$ & 0.07541 & 2.878 & 2.878 & 2.878 \\
\hline $\mathbf{C V} \%$ & $3.28 \%$ & $2.41 \%$ & $2.41 \%$ & $2.41 \%$ \\
\hline
\end{tabular}

Here, No: 0 kg N ha- ${ }^{-1}$ (control); $\mathrm{N}_{1}: 100 \mathrm{~kg} \mathrm{~N} \mathrm{ha-}^{-1} ; \mathrm{N}_{2}: 130 \mathrm{~kg} \mathrm{~N}^{-1}$

$\mathrm{P}_{0}: 0$ kg $\mathrm{P}_{2} \mathrm{O}_{5}$ ha-1 (control); $\mathrm{P}_{1}: 50 \mathrm{~kg} \mathrm{P}_{2} \mathrm{O}_{5}$ ha- ${ }^{-1}$; $\mathrm{P}_{2}: 80 \mathrm{~kg} \mathrm{P}_{2} \mathrm{O}_{5}$ ha- ${ }^{-1}$

Table 12: Comparison of the morphological feature and yield of chili in agricultural field to the rooftop for Capsicum

\begin{tabular}{|l|l|l|}
\hline Feature & Agricultural field & Rooftop garden \\
\hline $\begin{array}{l}\text { 1. Plant height } \\
\text { (cm) }\end{array}$ & $70-80$ & $55-92$ \\
\hline $\begin{array}{l}\text { 2. Number of } \\
\text { branch-1 plant }\end{array}$ & $15-20$ & $10-12$ \\
\hline $\begin{array}{l}\text { 3. Number of fruit } \\
\text { per plant }\end{array}$ & $300-400$ & $150-200$ \\
\hline 4. Yield (ton) & $8-10$ & $5-7$ \\
\hline
\end{tabular}

Source: Krishi Projockti Hathboi-7th edition-2017

\section{CONCLUSION}

Considering the above-mentioned results, it may be concluded that, different doses of nitrogen and phosphorus varied significantly for the growth and yield of Capsicum. The yield components and yield of Capsicum were positively influenced by the application of nitrogen and phosphorus on the rooftop garden. It was revealed that the application of $130 \mathrm{~kg} \mathrm{~N}$ ha- ${ }^{-1}$ along with $80 \mathrm{~kg} \mathrm{P}_{2} \mathrm{O}_{5}$ ha-1 $\left(\mathrm{N}_{2} \mathrm{P}_{2}\right)$ produces maximum yield and yield contributing characters of Capsicum in the rooftop garden. It can be suggested that growth and yield of Capsicum may be increased by using nitrogen and phosphorus which create a favourable climatic condition in the soil environment at the rooftop garden.

\section{REFERENCES}

[1] Smit, J., Ratta, A., Nasr, J. 1998. Urban agriculture: Food, jobs and sustainable cities. United Nations Development Programme, publication series for Habitat II, Vol. 1. New York: UNDP.

[2] Islam, K.M. 2004. Rooftop Gardening as a Strategy of Urban Agriculture for Food Security: The Case of Dhaka City, Bangladesh, Retrieved from teiep.gr: (http://wwwlib.teiep.gr/images/stories/acta/Acta\%20643/643_31.pdf).

[3] Wardard, Y. 2014. Rooftop gardening can meet Dhaka's 10pc of vegetable demand, Retrieved from thefinancialexpress-bd.com: (http://www.thefinancialexpress-bd.com/2014/11/19/66659/print). 
[4] Aman, F., Ishtiaq, M. 2002. Effect of different levels of nitrogen and plant spacing on the growth and yield of sweet pepper cv. yellow wonder, Sarhad Journal Of Agriculture Science, 18(3), 275-279.

[5] Aminifard, M.H., Aroiee, H., Ameri, A., Fatemi, H. 2012. Effect of plant density and nitrogen fertilizer on growth, yield and fruit quality of sweet pepper (Capsicum annum L.), African Journal of Agriculture Research, $7(6), 859-866$

[6] Singegol, H.Y. 1997. Effect of nitrogen and phosphorous on growth, yield and quality of green chili (Capsicum annum L.) Cv. Pusa Jwala, M Sc (Agricultural) Thesis, Uni Agricultural Science, Dharwad (India).

[7] Emilsson, T., Berndtsson, J.C., Mattsson, J.E., Rolf, K. 2007. Effect of using conventional and controlled release fertiliser on nutrient runoff from various vegetated roof systems, Ecological Engineering: the Journal of Ecotechnology, 29(3), 260-271.

[8] Berndtsson, J.C. 2010. Green roof performance towards management of runoff water quantity and quality: A review. Ecological Engineering: the Journal of Ecotechnology, 36(4), 351-360.

[9] Khurana, D.S., Rupinder, S., Sidhu, A.S., Ranjodh, S. 2006. Effect of different levels of nitrogen in split doses on growth and yield of chili, Indian Journal of Horticulture, 63, 467-469.

[10] Damke, M.M., Kawarkhe, V.J., Patil, C.U. 1990. Effect of phosphorus and potassium on the growth and yield of chili, PKV Research Journal, 12, 110-114.

[11] Lal, N., Pundrik, K.C. 1971. Effect of nitrogen, phosphorus and potassium on the growth and yield of chili, Punjab Hort. Journal, 11, 82-86.

[12] Sarma, U.J., Baruah, J.P.J., Suhrawardy, B.D., Chakravarty, M. 2004. Effect of various NPK levels on yield and capsaicin content in direct seeded chili (Capsicum annum), Indian Journal Hill Farming, 17(1/2), 15-18.

[13] Boroujerdnia, M., Ansari, N. 2007. Effect of different levels of nitrogen fertilizer and cultivars on growth, yield and yield components of romaine lettuce (Lactuca sativa L.), Middle Eastern and Russian Journal of Plant Science and Biotechnology, 1, 47-53.

[14] Ayodele, V.I. 2002. Influence of nitrogen fertilisation on yield of Amaranthus species. Acta horticulturae, 571: 89-95.

[15] Gastal, F., Lemaire, G. 2002. Nitrogen uptake and distribution in crops: an agronomical and ecophysiological perspective, Journal of Experimental Botany, 53, 789-799.

[16] Taylor, G., McDonald, A.J.S., Stadenberg, I., Freer-Smith, P.H. 1993. Nitrate supply and the biophysics of leaf growth in Salix viminalis, Journal of Experimental Botany, 44, 155-164. \

[17] Reddy, K.B., Reddy, D.S., Reddy, C.M. 1991. Evaluation of groundnut genotypes for phosphorus use efficiency, Indian Journal of Plant Physiological, 34, 228-234

[18] Rao, D.G., Subramanian, V.B. 1990. Effect of on nodulation. 1990. N harvest index and growth correlations between nodulation and other plant parts in cowpea under well-watered and dryland Condition. Indian Journal Of Plant Physiology, 33, 275-281.

[19] Gupta, C.R., Sangar, S.S. 2000. Response of tomato (Lycopersicon esculentum Mill.) to nitrogen and potassium fertilization in acidic soil of Bastar, International Journal Of Vegetable Science, 27(1), 94-95.
[20] Chauhan, V.L., Singh, R.V., Raghav, M. 2005. Optimum nitrogen and phosphorus fertilization in hybrid capsicum. Department of Vegetable Science, GBPUAT Hill Campus, Ranichauri 249199 (Uttaranchal), India Vegetable Science, 32(2), 200-202.

[21] Manchanda, A.K., Singh, B. 1988. Effect of plant density and nitrogen on growth and fruit yield of bell paper, Indian Journal of Agricultural, 33, 445-447.

[22] Tumbare, A.D., Bhoite, S.U. 2002. Effect of solid soluble fertilizer applied through fertigation on growth and yield of chili (Capsicum annum), Indian Journal Of Agricultural Sciences, 72(2), 109-111.

[23] Ludilov, V.A., Ludilova, M.I. 1977. The effect of high fertilizer rate on the yield and quality of the sweet peppers, Biryuchekutskaya Ovochnaya Stantsiya, USSR, 15, 50-53.

[24] Akanbi, W.B., Togun, A.O., Akinfasoye, J.O., Tairu, F.M. 2007. Physico-chemical properties of Eggplant (Solanum melongena L) fruit in response to nitrogen fertilizer and fruit size, Agricultural Journal, 2, 140148.

[25] Guohua, X.U., Kofkafi, U. 2001. Interaction effect of nutrient concentration and container volume on flowering, fruiting and nutrient uptake of sweet pepper, Journal of Plant Nutrition, 24(3), 479-501.

[26] Srivastava, B.K., Singh, M.P., Joshi, K. 2003. Standardization of nitrogen and phosphorus requirement for capsicum hybrid, Program Hort, 35(2), 202-204.

[27] Bahuguna, A., Singh, B., Bahuguna, S. 2014. Consequence of optimum levels of fertilizer on enlargement and yield of vegetable pea cv. VL ageti matar 7 under Uttarakhand hills condition, Journal Of Agronomy, 13(3), 153-157.

[28] Tumbare, A.D., Niikam, D.R. 2004. Effect of planting and fertigation on growth and yield of green chili (Capsicum annuum), Indian Journal Of Agricultural Sciences, 74, 242-245.

[29] Ogbomo, L., Egharevba, R.K.A. 2009. Effects of planting density and NPK fertilizer application on yield and yield components of tomato (Lycopersicum esculentum Mill.) in forest Location, World Journal of Agricultural Sciences, 5, 152-158.

[30] Jilani, M.S., Afzaal, M.F., Waseem, K. 2008. Effect of different nitrogen levels on growth and yield of brinjal, Journal of Agricultural Research, 46, 245-251.

[31] Tesfaw, A.N., Dechassa, W.T., Kebede, W.T. 2013. Performance of hot pepper (Cupsicum annuum L.) varieties as influenced by nitrogen and phosphorus fertilizers at bore, upper watershed of the Blue Nile in Northwestern Ethiopia, International Journal Of Agricultural Sciences, 3(8), 599-608.

[32] Naeem, N., Muhammad, I., Khan, J., Nabi, G., Muhammad, N., Badshah. N. 2002. Influence of various levels of nitrogen and phosphorus on the growth and yield of chili, Asian Journal Of Plant Science, 1(5), 599601.

[33] Awal, M.A., Ohta, T., Matsumoto, J., Toba, T., Daikoku, K., Hattori, S., Hiyama, T., Park, H. 2010. Comparing the carbon sequestration capacity of temperate deciduous forests between urban and rural landscapes in central Japan, Urban Forestry \& Urban Greening, 9, 261-270.

[34] Lau, T.C., Stephenson, A.G. 1994. Effects of soil phosphorus on pollen production, pollen size, pollen phosphorus content, and the ability to sire seeds in Cucurbita pepo (Cucurbitaceae), Sexual Plant Reproduction, 7(4), 215-220. 